\title{
Autoantibodies and the Hepatitis-associated Antigen in Acute Infective Hepatitis
}

\author{
L. J. FARROW,* M.R.C.P. ; E. J. HOLBOROW, † M.D. ; G. D. JOHNSON,‡ F.I.M.L.T. ; S. G. LAMB, \ M.B. \\ J. S. STEWART,\| M.R.C.P. ; P. E. TAYLOR,g PH.D. ; A. J. ZUCKERMAN, ${ }^{* *}$ M.D.
}

\begin{abstract}
Cummary: In 39 unselected patients with acute infective hepatitis diagnosed on clinical, epidemiological, and pathological findings, smooth muscle (S.M.) antibody was found in $87 \%$ and hepatitis-associated antigen in $33 \%$. The incidence of S.M. antibody was highest during the first month after the onset of symptoms, and the antibody was preponderantly IgM at this stage.

S.M. antibody and hepatitis-associated antigen occurred independently, and unlike hepatitis-associated antigen, which was strongly associated with possible parenteral exposure to infection, the incidence of S.M. antibody was not related to the presumed mode of exposure. It is concluded that production of S.M. antibody is more directly related to liver cell damage than to the presence of hepatitis-associated antigen in the serum.
\end{abstract}

\section{Introduction}

Autoantibodies in liver disease have been reported mainly in chronic active hepatitis, primary biliary cirrhosis, and cryptogenic cirrhosis (Johnson et al., 1965; Walker et al., 1965; Doniach et al., 1966). In these liver conditions smooth muscle antibody, antimitochondrial antibody, and antinuclear factor are considered to represent a group of tissue antibodies that are "markers" of an autoimmunizing process associated with continuing liver injury (Doniach and Walker, 1969).

In acute infective hepatitis the incidence of autoantibodies is not established. Two reports (Doniach et al., 1966; Wright, 1970), however, have mentioned that smooth muscle antibody is present in a minority of cases. The firm association that has recently been established between some forms of acute hepatitis and the presence in the serum of the hepatitisassociated antigen (Australia-SH antigen) (Zuckerman, 1969) has raised the question of whether a relationship exists between this antigen and autoimmune responses. In 78 patients with acute viral hepatitis Wright (1970) found no correlation between the presence of smooth muscle (S.M.) antibody and hepatitis-associated antigen, but was able to demonstrate S.M. antibody intermittently in only $19(24 \%)$. It thus seemed important to examine the incidence of autoantibodies in more detail by testing serial serum samples from well-documented patients with acute infective hepatitis. These samples were tested for S.M. antibody, antimitochondrial antibody, and antinuclear factor.

\section{Patients and Methods}

Thirty-nine unselected consecutive patients, diagnosed on clinical, epidemiological, and pathological findings as suffering from acute infective hepatitis (Zuckerman, 1970), were studied. Thirty-four were admitted to hospital and five were

\footnotetext{
* Senior Registrar, Department of Medicine, St. Mary's Hospital, London W.2. and West Middlesex Hospital, Isleworth, Middlesex.

† Member of Scientific Staff, Medical Research Council Rheumatism Unit, Canadian Red Cross Hospital, Taplow, Maidenhead, Berks.

¥Senior Technical Officer, Medical Research Council Rheumatism Unit, Canadian Red Cross Hospital, Taplow, Maidenhead. Berks.

SAssistant Physician, South Middlesex Hospital, Isleworth, Middlesex.

Consultant Physician, West Middlesex Hospital, Isleworth, Middlesex. gResearch Associate, London School of Hygiene and Tropical Medicine, London W.C.1.

**Reader in Virology, London School of Hygiene and Tropical Medicine, London W.C.1.
}

visited at home. All were clinically jaundiced at the time at which they were first seen and examined. The time of onset of symptoms was determined as accurately as possible, and the duration of the illness was calculated from this date. The patients were classified on epidemiological grounds with respect to the possible mode of exposure to infection as follows:

(1) Oral (6 males and 5 females).-Definite close (nonparenteral) contact with another case of jaundice within 60 days of the onset of symptoms.

(2) Parenteral (10 males and 5 females).-Known history of injections within six months of the onset of symptoms. Of the 15 patients in this group eight were known narcotic addicts.

(3) Unknown (7 males and 6 females).-No known history of exposure to either oral or parenteral infection.

The patients were examined weekly during the period of the acute illness and blood samples were collected at these times. They were seen again at intervals increasing from 2 to 12 weeks. The mean number of blood samples obtained by the end of the first month after the onset of symptoms was 2.3 , and over the whole period of assessment was 6 . Liver biopsy specimens were obtained from 16 of the 39 patients the histological appearances being consistent with the clinical diagnosis of acute infective hepatitis.

\section{Immunofluorescent Tests}

Fluorescein-labelled antihuman globulin reagents were prepared from class-specific rabbit antihuman IgG and sheep antihuman IgM sera by reacting the globulin fraction precipitated by half saturated $\left(\mathrm{NH}_{4}\right)_{2} \mathrm{SO}_{4}$ with fluorescein isothiocyanate (Isomer I) (B.D.H.) at $30 \mu \mathrm{g} . / \mathrm{mg}$. protein for 90 minutes at $\mathrm{pH} 9$ and room temperature. Unreacted dye was removed by filtration through Sephadex G50. The classspecific reactivity of the two conjugates was confirmed by results of testing known IgG and IgM antinuclear and other tissue antibodies. Sera were tested at $1 / 10$ dilution in duplicate with the two conjugates diluted $1 / 40$ and $1 / 10$ respectively. Composite cryostat sections of rat kidney, rat stomach, and rat liver were used as substrate for antimitochondrial, antismooth-muscle, and antinuclear antibodies. Sections were examined with a Reichert Zetopan microsoope, a cardioid darkground condenser being used, an $\mathrm{HBO} 200$ mercury vapour lamp, a BG12 3-mm primary filter, and a GG9 secondary filter.

\section{Immunodiffusion Tests}

Immunodiffusion tests were carried out by the method described by Zuckerman and Taylor (1969), the double diffusion micro-Ouchterlony technique as modified by Prince (1968) being used. Agarose gel $(0.9 \%)$ was prepared in a buffer containing $0.1 \mathrm{M}$ sodium chloride, $0.1 \mathrm{M}$ tris (hydroxymethyl) amino-methanol ( $p \mathrm{H} \quad 7.6$ at $25^{\circ}$ C.), $0.001 \mathrm{M}$ ethylenediaminetetra-acetic acid, and $1 \mathrm{mg} . / \mathrm{ml}$. protamine sulphate. Merthiolate was added to the gel to give a final concentration of $1 / 5,000$.

Tests were performed in $190-\mathrm{mm}$. Sterilin plastic Petri dishes containing $15 \mathrm{ml} .0 .9 \%$ agarose gel. A pattern of six equivalent wells surrounding a central well was used. The wells were $2.5 \mathrm{~mm}$. in diameter and $4 \mathrm{~mm}$. apart. Test sera 
were added to the peripheral wells and allowed to diffuse for 20 minutes before the addition of antiserum to the central well. The gel was kept in a moist chamber at room temperature and read daily for seven days.

The antiserum used to detect the hepatitis-associated (Australia-SH) antigen was obtained from a frequently transfused patient and gave reactions of identity with antisera anti-Au(1) (CO41177) obtained from Professor B. S. Blumberg, Philadelphia, anti-SH (Saunders 4X concentrated) provided by Dr. A. M. Prince, New York, and anti-Au-SH (donor F) supplied by Professor R. W. McCollum, New Haven. A positive control serum containing antigen was included in every test.

\section{Results}

Smooth muscle antibody was found during the course of the illness in 34 of the 39 patients (16 female, 23 male). Hepatitis-associated antigen was found in the sera of 13 patients. The use of anti-IgM conjugate increased the number of positive S.M. antibody tests, especially during the first month. Of the 27 patients positive at this time seven were positive by $\operatorname{IgM}$ testing only, and all except one of the remainder had both IgG and IgM S.M. antibody. Positive staining was noticeably stronger with anti-IgM than with anti-IgG in two-thirds of the serum samples tested at this time. When S.M. antibody was found several consecutive tests were of ten positive.

There was no correlation between the presence of S.M. antibody and the presence of hepatitis-associated antigen, either early in the illness or later (Table I). A striking difference was observed, however, between the incidence of S.M. antibody and the incidence of hepatitis-associated antigen when cases were considered according to possible mode of exposure to infection. While hepatitis-associated antigen was strongly associated with parenteral exposure, and was found in only one patient thought to have been infected orally, the mode of exposure to infection did not in any way affect the incidence of S.M. antibody (Table II). The incidence of S.M. antibody and hepatitis-associated antigen at different intervals after the onset of symptoms is shown in Table III. For both, the highest incidence was seen during the first month, with S.M. antibody showing more than twice the frequency $(82 \%)$ of hepatitis-associated antigen $(35 \%)$.

After the first month both tests became progressively less often positive, but the preponderance of S.M. antibody was still pronounced, as Table III shows. In 21 cases retested more than three months after the onset of symptoms S.M. antibody had persisted in, or had reappeared in, eight, while only 1 out of 24 cases similarly tested for hepatitis-associated antigen after this interval was positive. Antinuclear factor

TABLe I.-Lack of Correlation Between Presence of S.M. Antibody and Hepatitis-associated Antigen (H.A.A.)

\begin{tabular}{|c|c|c|c|c|c|c|}
\hline & \multicolumn{3}{|c|}{$\begin{array}{l}\text { During First Four Weeks. } \\
\text { No. of Patients With }\end{array}$} & \multicolumn{3}{|c|}{$\begin{array}{l}\text { At Any Time. } \\
\text { No. of Patients With }\end{array}$} \\
\hline & H.A.A. + & H.A.A. - & Total & H.A.A. + & H.A.A. - & Total \\
\hline $\begin{array}{l}\text { S.M. antibody + } \\
\text { S.M. antibody - }\end{array}$ & $\begin{array}{l}9 \\
3\end{array}$ & $\begin{array}{r}19 \\
3\end{array}$ & $\begin{array}{r}28 \\
6\end{array}$ & $\begin{array}{r}11 \\
2\end{array}$ & $\begin{array}{r}23 \\
3\end{array}$ & $\begin{aligned} 34 \\
5\end{aligned}$ \\
\hline Total & 12 & 22 & 34 & 13 & 26 & 39 \\
\hline
\end{tabular}

TABLE II.-Correlation Between Mode of Exposure and Presence of S.M. Antibody and H.A.A. at Any Time

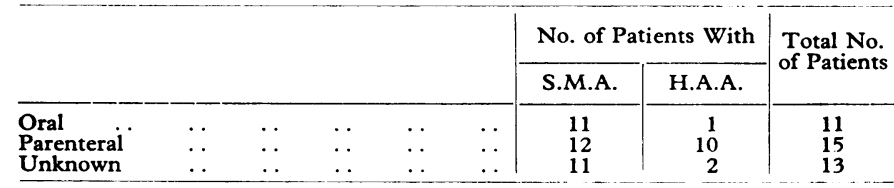

TABLE III.-Incidence of S.M. Antibody and Hepatitis-associated Antigen During Course of Acute Infective Hepatitis Weeks After Onset of Symptoms

\begin{tabular}{c|c|c|c|c|c|c|c|}
\hline \multicolumn{1}{|c|}{$1-4$} & \multicolumn{2}{c|}{$5-8$} & \multicolumn{2}{c|}{$9-12$} & \multicolumn{2}{c|}{$12+$} \\
\hline S.M.A.* & H.A.A. & S.M.A. & H.A.A. & S.M.A. & H.A.A. & S.M.A. & H.A.A. \\
\hline $\begin{array}{c}28 / 34 \dagger \\
(82 \%)\end{array}$ & $\begin{array}{c}12 / 34 \\
(35 \%)\end{array}$ & $\begin{array}{l}18 / 32 \ddagger \\
(56 \%)\end{array}$ & $\begin{array}{c}7 / 33 \neq \\
(21 \%)\end{array}$ & $\begin{array}{c}6 / 21 \neq \\
(28 \%)\end{array}$ & $\begin{array}{c}1 / 17 \neq \\
(6 \%)\end{array}$ & $\begin{array}{c}8 / 21 \neq \\
(38 \%)\end{array}$ & $\begin{array}{c}1 / 24 \ddagger \\
(4 \%)\end{array}$ \\
\hline
\end{tabular}

*IgG and/or IgM.
tFive patients were seen for the first time more than four weeks after onset of symptoms.
$\ddagger$ Not all samples obtained could be examined by both tests.

(IgG and/or IgM) showed no association with S.M. antibody; it was found during the first month in 9 of the 28 cases positive for S.M. antibody and in two of the six cases negative for S.M. antibody. Antinuclear factor, on the other hand, was significantly correlated $(\mathbf{P}<0.01)$ with hepatitis-associated $\omega_{\mathscr{S}}$ antigen (Table IV), though both were not necessarily present $\stackrel{D}{O}$ at the same time in a given patient. After the first month antinuclear factor was less often found, but it was noted that $\mathcal{N}$ among those patients retested more than three months after onset, seven of the eight with S.M. antibody were also posi- $\vec{\overrightarrow{ }}$ tive for antinuclear factor or had previously been positive, of while only 3 of the 13 cases negative for S.M. antibody at $\omega$ this time were or had been antinuclear factor positive. Fur- $\frac{\circ}{2}$ thermore, of the seven patients positive for both antinuclear $N$ factor and S.M. antibody when retested after more than three $\complement$ months, two were undergoing clinical and biochemical relapse, and two showed persistently abnormal biochemical tests. Patients negative for S.M. antibody on retesting after more than three months showed no clinical or biochemical abnormalities.

TABLE IV.-Correlation of Antinuclear Factor with Hepatitis-associated Antigen (Either Positive at Any Time) in the 39 Patients Tested

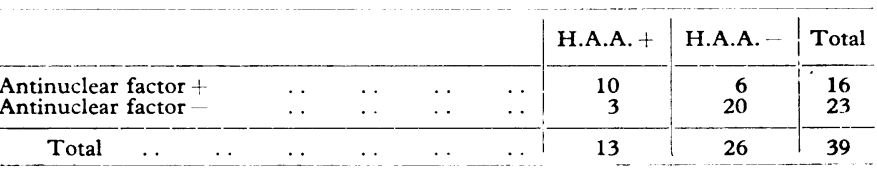

\section{Discussion}

These results show that most cases of acute infective hepatitis produce smooth muscle antibody, especially during $\stackrel{5}{3}$ the early weeks of the disease. At this stage antibody in the $N$ IgM class shows some preponderance over IgG. Though both $\rightarrow$ S.M. antibody and hepatitis-associated antigen are more often found during the early stages of acute infective hepatitis than $N$ later, there was no overall correlation between them in the N present study. Furthermore, S.M. antibody, unlike hepatitisassociated antigen, was unrelated to the presumed mode of exposure to infection. Conflicting results have been reported $\frac{0}{\Phi}$ on the clinical specificity of the hepatitis-associated antigen; $\stackrel{\mathscr{Q}}{\rightarrow}$ in several studies this antigen was found to be associated 0 with both the infectious and serum types of hepatitis (Blumberg et al., 1968; Gocke and Kavey, 1969; Cossart and Vahrman, 1970). Other investigators have associated this antigen $\mathbb{D}$ more specifically with serum hepatitis (Prince, 1968; Giles et al., 1969; Mosley et al., 1970). Our results confirm this association with serum hepatitis, and eight of our patients in this group were known drug addicts.

These findings suggest that liver cell damage in acute infective hepatitis is a more direct stimulus to S.M. antibody production than the presence of hepatitis-associated antigen. They also suggest that the liver cell damage in acute infective hepatitis and in chronic active hepatitis engender similar immunological stimuli, since S.M. antibody now proves to be 
almost as frequent an accompaniment of the former as of the latter. This role for liver cell damage is further supported by our findings that biochemical and clinical relapse in infective hepatitis seems to be accompanied by reappearance of S.M. antibody in the serum. Moreover, a positive antinuclear factor during the course of the illness may suggest persistent disease or relapse occurring. The patients will be followed further to obtain more evidence on this point.

We thank Mrs. Mavis Smith for her skilled technical assistance and Dr. R. A. Dale for the biochemical investigations, Dr. A. Knudsen for the biopsy reports, and the general practitioners who kindly referred patients to us. We are grateful to Dr. N. F. Coghill for referring patients and for his advice and encouragement. The work carried out at the London School of Hygiene and Tropical Medicine was aided by a grant from the Medical Research Council to A. J. Zuckerman, and at the West Middlesex Hospital by a grant from the hospital research fund to L. J. Farrow.
REFERENCES

Blumberg, B. S., Sutnick, A. I., and London, W. T. (1968). Bulletin of the New York Academy of Medicine, 44, 1566.

Cossart, Y. E., and Vahrman, J. (1970). British Medical fournal, 1, 403.

Doniach, D., Roitt, I. M., Walker, J. G., dnd Sherlock, S. (1966). Clinical and Experimental Immunology, 1, 237.

Doniach, D., and Walker, J. G. (1969). Lancet, 1, 813.

Doniach, D., and Walker, J. G. (1969). Lancet, 1, 813 . S. (1969). New England foumal of Medicine, 281, 119.

Gocke, D. J., and Kavey, N. B. (1969). Lancet, 1, 1055

Johnson, G. D., Holborow, E. J., and Glynn, L. E. (1965). Lancet, 2, 878 .

Mosley, J. W., Barker, L. F., Shulman, N. R., and Hatch, M. H. (1970). Nature, 225, 953.

Prince, A. M. (1968). Proceedings of the United States National Academy of Sciences, 60, 814. Walker, J. G., Doniach, D., Roitt, I. M., and Sherlock, S. (1965).

Wright, R. (1970). Lancet, 1. 521.

Zuckerman, A. J. (1969). Nature, 223, 569.

Zuckerman, A. J. (1970). Virus Diseases of the Liver. London, Butterworths.

Zuckerman, A. J., and Taylor, P. E. (1969). Nature, 223, 81.

\title{
Australia Antigen and Autoantibodies in Chronic Hepatitis
}

\author{
T. L. VISCHER,* M.D.
}

Cummary: The sera of 110 patients with chronic $\checkmark$ hepatitis and adequate controls were examined for antibodies to smooth muscle (S.M.), mitochondria (M.), and for antinuclear factors by the immunofluorescence method, and for Australia $(A u(1))$ antigen by a modified micro-Ouchterlony immunodiffusion technique. Twelve out of 13 patients with primary biliary cirrhosis had $M$. antibodies, two had antinuclear factor, and none had $A u(1)$ in their sera. In chronic aggressive hepatitis $23.5 \%$ of the sera contained antinuclear factor, $13 \%$ S.M. antibodies, $10.5 \% \mathrm{M}$. antibodies, and $22 \% \mathrm{Au}(1)$ antigen. Of the 12 patients with chronic persistent hepatitis, one had antinuclear factor, one S.M. antibodies, and three Au(1) antigen.

The most striking finding was a mutual exclusion between $A u(1)$ antigen and $M$. and S.M. antibodies. None of the 33 patients with one or the other form of chronic hepatitis and $M$. or S.M. antibodies had $A u(1)$ antigen; 22 out of $77(28 \%)$ patients without such antibodies were positive.

\section{Introduction}

Studies of the various autoantibodies in chronic hepatitis have already been extensively reported. These antibodies are usually detected by immunofluorescence. Antinuclear factors (Paronetto et al., 1961), non-organ-specific cytoplasmic antibodies (M. antibodies) (Walker et al., 1965), and antibodies against smooth muscle (S.M. antibodies) (Johnson et al., 1965) are most frequently determined. Their presence is usually taken as an indicator of deranged immunity, and autoimmune processes are believed to play a part in the pathogenesis of this group of diseases.

The Australia antigen $\mathrm{Au}(1)$ is presumed to be a component of a virus which can cause active hepatitis (Blumberg et al., 1969; Briţish Medical fournal, 1970); it is identical wit' the SH antigen of Prince (1968b). At least two serological types of hepatitis virus exist, which differ in incubation period

* Consultant in Clinical Immunology, Department of Medicine, Immunology Laboratory, Bürgerspital, 4000 Basel, Switzerland, and Study Group for Chronic Hepatitis, Swiss Society of Gastroenterology.
(Krugman et al., 1967). Only serum of long-incubation-period hepatitis is $\mathrm{Au}(1)$-positive (Giles et al.. 1969). Wright et al. (1969a) suggested that active chronic hepatitis is perpetuated in some cases by a hepatitis virus related to $\mathrm{Au}(1)$ antigen.

To date there has been no systematic study of the various autoantibodies in relation to the occurrence of $\mathrm{Au}(1)$ antigen in chronic hepatitis. The sera ccllected during a collaborative clinical study of chronic hepatitis in Switzerland were examined for antinuclear factor, M. and S.M. antibodies, and $\mathrm{Au}(1)$ antigen. In this report their incidence, especially in chronic aggressive hepatitis, is evaluated and the implications of the results on pathogenesis are discussed.

\section{Patients and Methods}

\section{Sera}

Sera were obtained from patients included in a study of chronic hepatitis (Swiss Society of Gastroenterology, Study Group of Chronic Hepatitis). Diagnosis of chronic hepatitis was made by histological examination together with the clinical, biochemical, and other findings. Chronic aggressive hepatitis and chronic persistent hepatitis are defined as described by DeGroote et al. (1968) and primary biliary cirrhosis (=chronic non-suppurative destructive cholangitis) as described by Rubin et al. (1965). Some of the patients had developed cirrhosis and some were receiving steroids, azathioprine, or both when serum samples were taken. Where multiple samples at different time intervals were available, only the first one was included in this study. Clinical data and changes in titres during the course of the disease will be reported elsewhere. The sex and age distribution of the patients studied is shown in Table I. In the group consisting of "various liver diseases" are included alcoholic cirrhosis (5), extrahepatic biliary obstruction (10), drug-induced cholestasis (5), reactive hepatitis (5), acute hepatitis (20), acute hepatitis, reconvalescence period (13). Normal sera were obtained from blood donors. The other control sera were sent to this laboratory for determination of antinuclear factor from patients of this hospital with various diseases and clinical suspicion of immune diseases. Some of the sera were kept at $-20^{\circ} \mathrm{C}$. for up to two years. 